\title{
ESI-MS Study of Speciation in Hydrolyzed Aluminum Chloride Solutions
}

\author{
Mirjana Cvijović, ${ }^{a}$ Vesna Kilibarda, ${ }^{b}$ Milena Jelikić-Stankov, ${ }^{c}$ Ivan Lazarević, ${ }^{d}$ \\ Ivan Jakovljević, ${ }^{e}$ Ljubinka Joksoviće ${ }^{\text {and Predrag Đurđević*,e }}$
}

\author{
${ }^{a}$ The Copper Mill, Sevojno, 31000 Užice, Serbia \\ ${ }^{b}$ Military Medical Academy, 11000 Belgrade, Serbia \\ ${ }^{c}$ Chair of Analytical Chemistry, Faculty of Pharmacy, 11000 Belgrade, Serbia \\ ${ }^{d}$ CBRN Training Center of the Serbian Armed Forces, 37000 Kruševac, Serbia \\ ${ }^{e}$ Chemistry Department, Faculty of Science, P.O. Box 60, 34000 Kragujevac, Serbia
}

\begin{abstract}
Soluções de $\mathrm{AlCl}_{3}$ foram analisadas em concentrações de 0,03 a 5,0 mmol dm-3 e pH de 3,5 a 6,0 por espectrometria de massas com ionização por electrospray e analizador quadrupolar (ESI-Q-MS). Esses dados espectrais foram comparados com os obtidos por ressonância magnética nuclear $(\mathrm{NMR}) \mathrm{de}{ }^{27} \mathrm{Al}$ e potenciometria. Espécies resultantes da hidrólise do cátion alumínio em solução apresentaram-se principalmente como complexos carregados positivamente $(+1)$ com moléculas de água coordenadas $(\mathrm{n}=1-3)$ ao metal. As análises revelaram que complexos poliméricos de carga +2 e +3 (em concentrações mais elevadas de $\mathrm{Al} \mathrm{e} \mathrm{pH}>4$ ) contêm íons cloretos coordenados. $\mathrm{O}$ aspecto geral dos espectros de massas é dependente de parâmetros instrumentais tais como taxa de fluxo de solvente, temperatura na fonte de ionização e voltagens do cone e capilar. Assim, o ajuste fino do instrumento com relação a estes parâmetros foi realizado. Uma tensão de cone de amostra não superior a $50 \mathrm{~V}$ levou à melhor correspondência entre dados de potenciometria, ressonância magnética nuclear de ${ }^{27} \mathrm{Al}$ e espectrometria de massas.
\end{abstract}

Solutions of $\mathrm{AlCl}_{3}$ were analyzed at concentrations from 0.03 to $5.0 \mathrm{mmol} \mathrm{dm}{ }^{-3}$ and $\mathrm{pH}$ from 3.5 to 6.0 using an electrospray ionization quadrupole mass spectrometer (ESI-Q-MS). Mass spectral data were compared with those obtained by ${ }^{27} \mathrm{Al}$ nuclear magnetic resonance (NMR) spectroscopy and potentiometry. Hydrolytic aluminum species were present in solution mainly as +1 positively charged complexes with $n$ coordinated water molecules $(n=1-3)$. Analysis revealed that polymeric complexes of +2 and +3 charges (at higher $\mathrm{Al}$ concentrations and $\mathrm{pH}>4$ ) contained coordinated chloride ions. The general appearance of the mass spectra is dependent on instrumental parameters such as solvent flow rate, ionization source temperature and cone and capillary voltages. Thus, fine tuning of the instrument with respect to these parameters was performed. Sample cone voltages not exceeding $50 \mathrm{~V}$ led to the best agreement between potentiometric, ${ }^{27} \mathrm{Al} \mathrm{NMR}$ and mass spectral data.

Keywords: aluminum, hydrolysis, mass spectrometry

\section{Introduction}

Aluminum ions are extremely prone to hydrolysis due to their high affinity toward negatively charged oxygen. Several excellent reviews devoted to various aspects of aluminum hydrolysis, summarizing data accumulated over several decades, were published. ${ }^{1-6}$ The extent of hydrolysis and the identity and stability of the hydrolytic species formed in solution depend upon many factors,

*e-mail: preki@kg.ac.rs such as the nature and concentration of the supporting ionic medium, $\mathrm{pH}$, nature and concentration of the base used to force hydrolysis, aging time and presence of other substances that may interact with aluminum(III) and/or with water molecules. ${ }^{7-26}$ So, to fit the observed experimental data, various models for aluminum hydrolysis, including low molecular weight (lmw), oligomers (omw) and higher molecular weight polymers (hmw), have been proposed. . $^{1,47-35}$

Various transformations of $\mathrm{Al}$ species in solution such as hydrolysis, polymerization, flocculation, precipitation and 
crystallization can be described by two general models, namely "core + link" and "cage-like" Keggin, $\mathrm{Al}_{13}$. These models were reviewed by Bi et al. ${ }^{36}$ The "core + link" model is best suited for the explanation of transient state processes under moderate rate of base injection during the titration of $\mathrm{Al}$ solutions. According to this model, hydroxyl-Al changes from monomeric to polymeric through the continuous speciation change from small polymer (linear shape) $\rightarrow$ intermediate-size polymer (2D-planar shape) $\rightarrow$ large polymer, following an hexameric ring model. The structure of the polymers is the same as that of $\mathrm{Al}(\mathrm{OH})_{3}$, in which the basic units are either single or double hexameric rings. The most stable polymer is two-dimensional $\mathrm{C}-\mathrm{Al}_{13}{ }^{9+}$, which self-assembles to three-dimensional

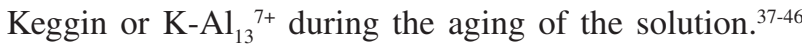
The amorphous Al-hydroxide is formed through a surface coordination process or a gradual growth process from $\left[\mathrm{Al}(\mathrm{OH})_{3}\right]_{\mathrm{n} \text { (aq) }}(\mathrm{n}=2-12)$ to sediment $\left[\mathrm{Al}(\mathrm{OH})_{3}\right]_{\mathrm{n}}(\mathrm{n} \rightarrow \infty)$ in the $\mathrm{pH}$ region from 4 to 7 . In a "cage-like" model, the hydrolyzed Al solutions contain only monomeric, dimeric, Keggin Al-13 polymeric and some larger polymerized Al species. Prolonged aging of weakly acidic aluminum solutions at elevated temperatures yields polynuclear species including $\left[\mathrm{Al}_{30} \mathrm{O}_{8}(\mathrm{OH})_{56}\left(\mathrm{H}_{2} \mathrm{O}\right)_{26}\right]^{18+}$, referred to as $\mathrm{Al}_{30}$-mer. ${ }^{10}$ Polymeric species are metastable and during the aging step undergo structural re-organization. These species can be transformed from one to another directly. The $\mathrm{K}-\mathrm{Al}_{13}$ transforms slowly to $\mathrm{Al}(\mathrm{OH})_{3}$ through the aggregation, in the process of aging, of partially hydrolyzed $\mathrm{Al}$ species. ${ }^{47}$ Bi et $a l .{ }^{36}$ summarized both models into the following scheme: at an average hydroxyl to aluminum ratio (defined as $\mathrm{Z}=[\mathrm{OH}] /[\mathrm{Al}]), Z c a .0 .2)$, only hexa-aqua $\mathrm{Al}^{3+}, \mathrm{Al}(\mathrm{OH})^{2+}$, $\mathrm{Al}(\mathrm{OH})_{2}{ }^{+}$and $\mathrm{Al}(\mathrm{OH})_{3 \text { (aq) }}{ }^{0}$ exist in solution together with small polymers of general formula $\mathrm{Al}_{\mathrm{m}}(\mathrm{OH})_{\mathrm{Zm}}{ }^{(3 \mathrm{~m}-\mathrm{Zm})+}$. The polymers exist as transient species up to $Z c a$. 2.5. Beyond this value, the main $\mathrm{Al}$ species are large $\mathrm{Al}_{13}-\mathrm{Al}_{54}$ polymers and sol/gel $\mathrm{Al}(\mathrm{OH})_{3}$. The polymer charges range between +7 to +18 . At higher values of $Z$, precipitation occurs by aggregation of polymeric species, so that the main constituents of the solution are $\left[\mathrm{Al}(\mathrm{OH})_{3}\right]_{\mathrm{n}(\mathrm{aq})}$ and $\mathrm{Al}_{\mathrm{x}} \mathrm{O}_{\mathrm{z}}(\mathrm{OH})_{\mathrm{y}}{ }^{(3 x-y-2 z)+}$. At the same time, the gel begins to dissolve $(\mathrm{pH}>6)$ and the soluble $\mathrm{Al}(\mathrm{OH})_{4}^{-}$complex forms. ${ }^{36,45}$

Recently, much useful information concerning the identity of hydrolyzed aluminum species has been obtained by mass spectrometric measurements. $48-54$ "Soft" ionization techniques such as electrospray ionization mass spectrometry (ESI-MS) were extensively used. ESI-MS spectra do not exactly represent the speciation picture of the solution "before the measurement" due to perturbations occurring after the sample injection in the ion source and before the ion detection. Therefore, the experimental conditions should be adjusted in such way that nebulization and desolvation do not disturb labile hydrolytic process in the solution. Also, the change in the $\mathrm{pH}$ of the droplet environment (due to its decrease in volume) does not cause charge reduction in the hydrolytic complexes pinched out from the droplet.

The most comprehensive ESI-MS study of aluminum hydrolysis was performed by Sarpola et al. ${ }^{51-54}$ They reported several different anionic and cationic $\mathrm{Al}$-complexes ranging from monomeric to polymeric species $\left(\mathrm{Al}_{30}\right)$ in chloride, sulfate and mixed chloride and sulfate media. The effect of the anion on speciation was also studied. By using the ESI-TOF-MS (electrospray ionization-time of flight-mass spectrometry) technique, they found three different $\mathrm{pH}$ ranges in which the speciation of Al differed from each other: at $\mathrm{pH} c a .3$ the dominant forms were dimeric $\left[\mathrm{Al}_{2} \mathrm{O}(\mathrm{OH})_{2} \mathrm{Cl}\left(\mathrm{H}_{2} \mathrm{O}\right)_{0-3}\right]^{+}$and trimeric $\left[\mathrm{Al}_{3} \mathrm{O}(\mathrm{OH})_{4} \mathrm{Cl}_{2}\left(\mathrm{H}_{2} \mathrm{O}\right)_{0-3}\right]^{+}$, while at $\mathrm{pH}$ ca. 5 larger polymers with the $\mathrm{Al}_{13}$ core were dominant. The charge of these complexes ranged from -2 to +3 , and the disagreement with the +7 charge of Keggin polymers was explained by the presence of terminal chloro atoms. At neutral $\mathrm{pH}$, the formation of colloids and precipitates was indicated by the loss of all signals from the spectra. The largest aluminum cation found by Sarpola et al. ${ }^{51}$ was the $\mathrm{Al}_{30}$ cluster as $\left[\mathrm{Al}_{30} \mathrm{O}_{35}(\mathrm{OH})_{17}\right]^{3+}$. In more recent work, ${ }^{54}$ the results obtained by ESI-TOF-MS were re-investigated by using tandem mass spectrometry with triple-quadrupole instrument. No anionic spectra were observed. Signals of the monomeric complexes $\left[\mathrm{Al}(\mathrm{OH})_{2}\right]^{+}$and $\left[\mathrm{Al}(\mathrm{OH})_{2}\left(\mathrm{H}_{2} \mathrm{O}\right)_{\mathrm{n}}\right]^{+}$ $(\mathrm{n}=1,2,3)$ dominated the full scan spectra. At higher collisional energy, two hydroxo groups formed a bridging oxo ligand, with the loss of one water molecule. Chloro ligands were not present as bridging ions since at even low collisional energies they were eliminated as $\mathrm{HCl}$. It was observed that even small dimeric and trimeric complexes were able to capture aqua ligands and the fragment ion spectra broadened toward higher $\mathrm{m} / \mathrm{z}$, values. ESI-MS was also applied to aluminum hydrolysis studies in very diluted aluminum chloride solutions by Zhao et al. ${ }^{50}$ They divided all hydrolytic species into four groups. The first group, formed at $\mathrm{pH} c a .4$, consisted of monomeric and dimeric species. At $\mathrm{pH} c a .4 .8$, trimeric to pentameric species formed and upon raising the $\mathrm{pH}$ to $c a$. 5.0, these species polymerized to higher oligomers from $\mathrm{Al}_{6}$ to $\mathrm{Al}_{10}$. The fourth group contained the polymerization products from $\mathrm{Al}_{11}$ to $\mathrm{Al}_{21}$, and finally flocks appeared at $\mathrm{pH} c a$. 6.4. Urabe et al. ${ }^{48,49}$ studied the speciation of aluminum hydrolytic complexes in chloride solutions by applying ESI-Q-MS (electrospray ionization-quadrupole- 
mass spectrometry), ESI-Q-MS/MS (electrospray ionization-quadrupole-tandem mass spectrometry) and ESI-TOF-MS measurements. Hydrolysis was not forced by the addition of base, i.e., it was carried out in the aluminum concentration range of 0.02 to $100 \mathrm{mmol} \mathrm{dm}^{-3}$ without $\mathrm{pH}$ adjustment. Aluminum species existed in solution mainly as positively charged monomeric aluminum hydroxides with several water molecules. In addition to monomers, some polymers were identified $\left(\mathrm{Al}_{2}, \mathrm{Al}_{3}, \mathrm{Al}_{4}\right.$ and $\left.\mathrm{Al}_{5}\right)$ with +1 charge. In positive mode, no complexation with chloride was observed. According to Urabe et al. ${ }^{48}$, in partially neutralized $\mathrm{AlCl}_{3}$ solution $\left(\mathrm{C}_{\mathrm{Al}}=1 \mathrm{mmol} \mathrm{dm}^{-3}, Z=1.5\right)$, triply charged tridecamer and doubly charged tridecamer, $\mathrm{Al}_{13}{ }^{2+}$, were observed at $m / z, 279-309$ and $m / z=409+9$ n $(n=0-7)$ respectively. Tridecameric species differed by the number of water molecules in the cluster.

Available literature data indicate that the main problem encountered in ESI-MS studies of aluminum hydrolysis is the correspondence between equilibrium state in solution and species present in the MS source (gas phase reaction). Generally, classical methods (potentiometry, multinuclear magnetic resonance (MR) spectroscopy and spectrophotometry) identified much less species than ESI-MS, indicating that most species observed by MS are rather characteristic of the MS gas phase than of the solution. Thus, optimal tuning of the mass spectrometry instrument should be performed in order to obtain maximum agreement between spectral and potentiometric data. It has been established in previous work ${ }^{49}$ that ESI-Q-MS preserves the dissolution state of aluminum ion better than ESI-TOF-MS.

In the present work, the hydrolysis of aluminum chloride under various conditions using the ESI-Q-MS technique was studied to establish a correspondence between real speciation in hydrolyzed aluminum solutions and signals obtained in ESI-MS. From such set of known species, it would be in principle possible to establish the realistic model of hydrolysis, i.e., to give the preference to some of the above described models.

\section{Experimental}

\section{Reagents}

The standard aluminum chloride solution was prepared by dissolving Al sheets (99.98\% purity, Merck, Darmstadt, FRG) in $\mathrm{HCl}$ (Suprapure, Merck). The content of aluminum was checked by gravimetry and ICP-OES (inductively coupled plasma - optical emission spectrometry). The aluminum concentration was $0.1000 \pm 0.0005 \mathrm{~mol} \mathrm{dm}^{-3}$. The content of strong acid $(\mathrm{HCl})$ in the aluminum solution was determined potentiometrically using the Gran method, and the concentration of $\mathrm{HCl}$ was $0.153 \pm 0.002 \mathrm{~mol} \mathrm{dm}^{-3}$. Methanol (P.A., Merck) was distilled twice before use. Formic acid and $\mathrm{NaOH}$ were reagent grade purity (Merck). Tetramethylammonium hydroxide (TMA) and ammonium hydroxide were Sigma-Aldrich products (Austria).

\section{Instruments}

ESI-MS spectra were recorded on a Waters (Milford, USA) LC/MS instrument equipped with a Micromass model ZQ 2000 API single quadrupole mass detector, operating under the control of the MassLynx 4.0 software. The instrument was used as a simple ESI-MS equipment, i.e., the column was by-passed. Samples were introduced by flow injection analysis with either water or water/methanol $50: 50(\mathrm{v} / \mathrm{v} \%)$ as solvent flow phase with a flow rate of $0.2 \mathrm{~mL} \mathrm{~min}^{-1}$. The sample was introduced into the ESI probe by manual injection with the use of a Hamilton Microliter syringe. Samples were also introduced by continuous flow at $10 \mu \mathrm{L} \mathrm{min}{ }^{-1}$. Spectra were taken in positive mode. For $\mathrm{pH}$ measurements, a Mettler Toledo DL 50 instrument equipped with a radiometer combined electrode was used.

Optimal MS conditions were established by a series of preliminary experiments and the best operational parameters were: capillary voltage $3.5 \mathrm{kV}$, cone voltage $50 \mathrm{~V}$, extractor voltage $3 \mathrm{~V}$, source temperature $125^{\circ} \mathrm{C}$, desolvation temperature $200{ }^{\circ} \mathrm{C}$ and dynamic range $\mathrm{m} / \mathrm{z}$ 40-1000.

The solvent used was aqueous formate buffer. The cone (nitrogen) and desolvation gas flows were set at 50 and $450 \mathrm{~L} \mathrm{~h}^{-1}$ respectively.

${ }^{27} \mathrm{Al}$ NMR spectra were recorded at $130.28 \mathrm{MHz}$ on a Bruker DRX spectrometer with $\mathrm{AlCl}_{3}$ in $6.0 \mathrm{~mol} \mathrm{dm}^{-3} \mathrm{HCl}$ as external standard. Digital resolution was $1.27 \mathrm{~Hz}$ per point.

Potentiometric titrations were performed with a Radiometer DTS 800 titrator (Copenhagen, Denmark) equipped with a Radiometer combined electrode.

\section{Results}

Hydrolyzed aluminum samples were prepared in the following way: a volume of the $\mathrm{AlCl}_{3}$ stock solution was diluted with water to the desired concentration and the $\mathrm{pH}$ of the solutions was adjusted to the 3.2-6.0 range by addition of either $\mathrm{NaOH} / \mathrm{HCl}$ or formic acid/ $\mathrm{NH}_{4} \mathrm{OH}$. Solutions were aged either for $4 \mathrm{~h}$ or for 7,15 or 30 days. During the aging period, the $\mathrm{pH}$ value was periodically checked, and the values stable to $0.01 \mathrm{pH}$ units for $15 \mathrm{~min}$ were recorded. 
The nature of the resulting mass spectrum was dependent on various parameters such as applied voltages, solvents, $\mathrm{pH}$ and concentration of the solutions. First, the effect of voltages at the electrospray needle, $\mathrm{RF}$ lens and sample cone was investigated on $\mathrm{AlCl}_{3}$ plus quercetin solutions $\left(\mathrm{C}_{\mathrm{Al}}=5 \times 10^{-6} \mathrm{~mol} \mathrm{dm}^{-3}\right.$, $\left.\mathrm{C}_{\text {quercetin }}=1 \times 10^{-5} \mathrm{~mol} \mathrm{dm}^{-3}\right)$, according to Deng and Berkel..$^{55}$ The potentials were varied in the range of 2.0 to $4.5 \mathrm{kV}$ at the needle, 0 to $200 \mathrm{~V}$ at the cone and 0 to $20 \mathrm{~V}$ at the lenses. These conditions were adjusted to produce the $\left[\mathrm{Al}(\text { quercetin- } \mathrm{H})_{2}\right]^{+}$complex as the dominant ion. ${ }^{55}$ It was found that the intensity of the $\left[\mathrm{Al}(\text { quercetin- } \mathrm{H})_{2}\right]^{+}$ pseudo-molecular ion signal at $\mathrm{m} / \mathrm{z}, 629$ decreases with increasing cone voltages and is almost independent of the $\mathrm{RF}$ lens voltages. So, the voltage at the needle was kept at $3.5 \mathrm{kV}$. The sample cone voltage was further investigated on $5.0 \times 10^{-4} \mathrm{~mol} \mathrm{dm}^{-3}$ aluminum chloride solutions at pH 4.20. This voltage was varied between 10 and $200 \mathrm{~V}$ $(10,20,45,50,70,100,150$ and $200 \mathrm{~V})$. Along with voltages, the desolvation temperature $\left(200-300^{\circ} \mathrm{C}\right)$ and gas flow $\left(300-450 \mathrm{~L} \mathrm{~h}^{-1}\right)$ were varied. The optimum area and clean baseline were obtained at cone voltages of $45-50 \mathrm{~V}$, even for low intensity signals. The optimum desolvation temperature was set at $200{ }^{\circ} \mathrm{C}$ since higher temperatures produced a high number of low intensity signals. When the cone voltage was raised to $150 \mathrm{~V}$, the signals of $\mathrm{m} / \mathrm{z}$ higher than 300 became more intense and the observable spectral area extended toward higher $\mathrm{m} / \mathrm{z}$ values. At the same time, the background noise increased and low intensity signals became indistinguishable from the background. A sample cone voltage of $200 \mathrm{~V}$ increased the noise and the amount of overlapping signals in the cationic spectra. The final optimal conditions are listed in Table 1. Some of the obtained ESI-MS spectra at different cone voltages are shown in Figure 1.

Table 1. Optimal instrumental conditions for ESI-MS measurements

\begin{tabular}{lc}
\hline Parameters & \\
\hline Sample flow rate & $10 \mu \mathrm{L} \mathrm{min}^{-1}$ \\
Capillary voltage & $3.5 \mathrm{kV}$ \\
Sample cone voltage & $50 \mathrm{~V}$ \\
Extractor voltage & $3 \mathrm{~V}$ \\
R.f. lens & $5 \mathrm{~V}$ \\
Source temperature & $125^{\circ} \mathrm{C}$ \\
Desolvation temperature & $200^{\circ} \mathrm{C}$ \\
Mass range & $m / z 40-1000$ \\
Resolution & 2000 \\
Cone gas flow rate & $50 \mathrm{~L} \mathrm{~h}^{-1}$ \\
Desolvation gas flow rate & $450 \mathrm{~L} \mathrm{~h}^{-1}$ \\
\hline
\end{tabular}

The composition of the solvent also influences the appearance of the spectra. The spectra were recorded using water or water/methanol as solvents $(\mathrm{pH} 4.20)$. The most distinctive feature of the spectra was seen at $\mathrm{m} / \mathrm{z}, 61$ and was assigned to the dihydroxo complex, $\left[\mathrm{Al}(\mathrm{OH})_{2}\right]^{+}$. In the spectrum recorded using a water/ammonium formate to methanol rate of $90: 10(\mathrm{v} / \mathrm{v} \%)$, this signal disappears, indicating that the lowering of the solvent dielectric constant and surface tension is unfavorable for polyol formation.

In order to study the speciation of $\mathrm{Al}^{3+}$ hydrolytic complexes, the ESI-MS spectra were recorded at different $\mathrm{pH}$ values (3.20 to 6.20$)$ and at a constant aluminum concentration of $2.7 \times 10^{-5} \mathrm{~mol} \mathrm{dm}^{-3}$ under the optimal operational conditions. Clear solutions were observed up to $\mathrm{pH}$ 5.00; at this $\mathrm{pH}$ value, the solutions were stable for a prolonged period of time up to two days (i.e., no turbidity or precipitation was observed). At higher $\mathrm{pH}$ values, the solutions stayed clear for 2-3 $\mathrm{h}$ after the addition of base, and then a gradual turbidity developed. Most of the ESI-MS signals in solutions of $\mathrm{pH}$ between 5.50 to 6.20 disappeared. A representative spectrum at pH 3.59 is shown in Figure 2 and the identified species are given in Table 2.

The majority of the species identified in ESI-MS spectra were singly charged. Since the $\mathrm{Al}^{3+}$ aqua ion is present in all solutions, the formation of mononuclear $\mathrm{Al}-\mathrm{OH}$ species may proceed in the gas phase, through charge reduction during the dehydration process:

$$
\left[\mathrm{Al}\left(\mathrm{H}_{2} \mathrm{O}\right)_{6}\right]^{3+} \rightarrow\left[\mathrm{Al}(\mathrm{OH})_{\mathrm{n}}\left(\mathrm{H}_{2} \mathrm{O}\right)_{6-\mathrm{n}}\right]^{(3-\mathrm{n})+}+\mathrm{nH}_{3} \mathrm{O}^{+}
$$

ESI-MS spectra of hydrolyzed aluminum solutions were also indicative of the presence of various polynuclear hydrolytic complexes containing $\mathrm{Al}_{2}-\mathrm{Al}_{7}$ cores. The singly charged complexes predominate. Each complex ion was identified by its $\mathrm{m} / \mathrm{z}$, value, though different complexes containing $(\mathrm{OH})_{2}{ }^{2-}$ and $\mathrm{O}(\mathrm{OH})^{2-}$ groups may correspond to identical $\mathrm{m} / \mathrm{z}$ values. When chloride ions were coordinated to $\mathrm{Al}$, then the chlorine isotopic distribution was employed for identification of the Al-complexes. The $\left[\mathrm{AlCl}_{3}+\mathrm{H}^{+}\right]$and $\left[\mathrm{AlCl}_{2}\right]^{+}$signals were seen at $\mathrm{m} / z, 133$ and 97 , respectively. These species are not characteristic of the solutions and have probably been formed during the nebulization process. Intensive signals in the $m / z 60-100$ region were assigned to binary mononuclear hydroxo complexes, i.e., $[\mathrm{Al}(\mathrm{OH})]^{2+}$ and $\left[\mathrm{Al}(\mathrm{OH})_{2}\right]^{+}$. These complexes are characteristic of low concentration, hydrolyzed $\mathrm{Al}$ solutions and form rapidly and reversibly. ${ }^{1-8} \mathrm{The}\left[\mathrm{Al}(\mathrm{OH})_{2}\right]^{+}$ species may contain up to two water molecules in the coordination sphere. 

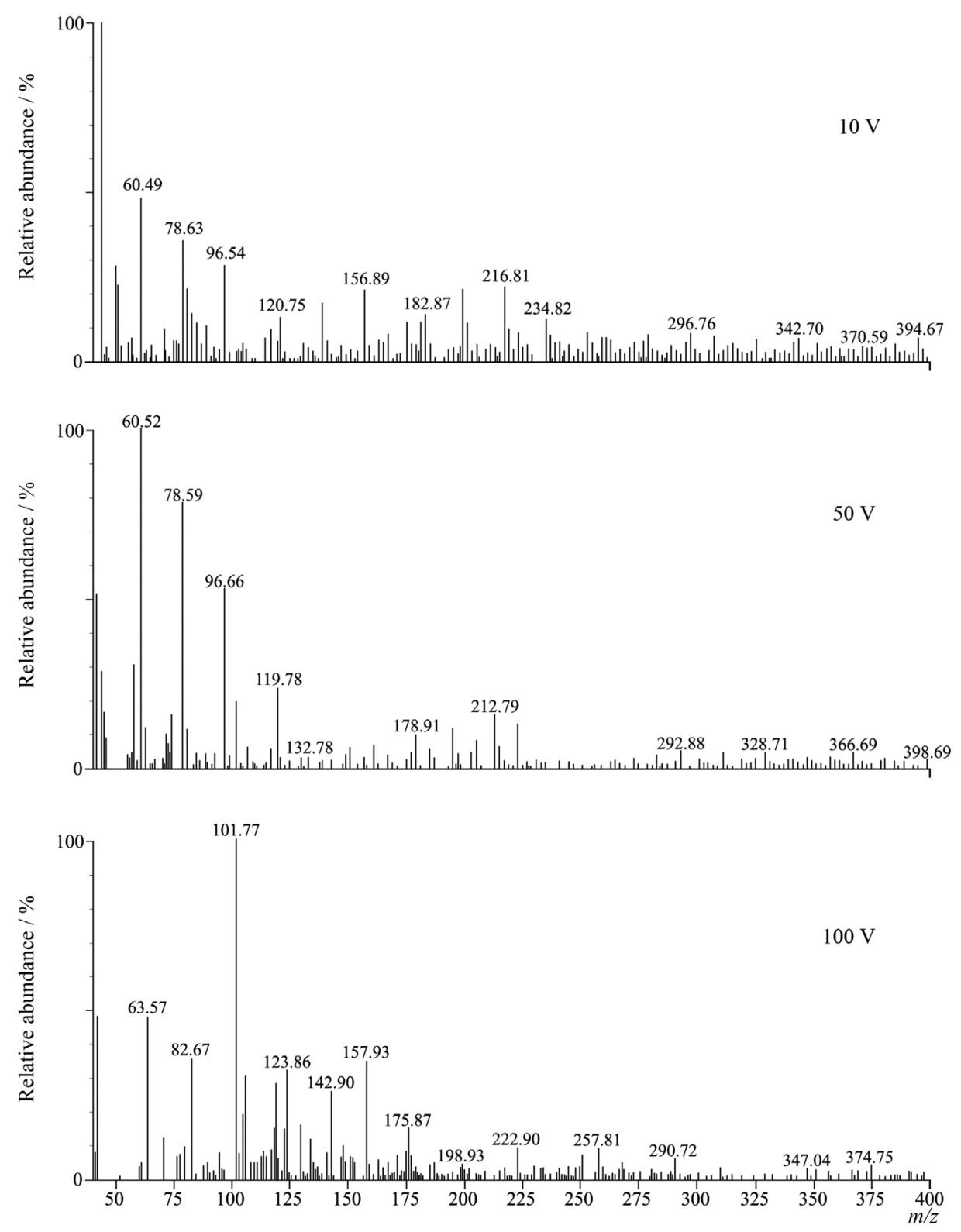

Figure 1. ESI-MS spectra of a $5.0 \times 10^{-4} \mathrm{~mol} \mathrm{dm}^{-3} \mathrm{AlCl}_{3}$ solution, $\mathrm{pH} 4.20$, at various cone voltages.

Some polymeric species appear as hydrated or chloro species whose charge was always found to be +1 . This leads to the conclusion that these species may contain, in their structures, bridging oxo or hydroxo groups. Other polymeric species containing the $\mathrm{Al}_{3}, \mathrm{Al}_{4}, \mathrm{Al}_{5}$ and $\mathrm{Al}_{7}$ cores were much less abundant at micromolar aluminum concentrations. The $\mathrm{Al}_{3}$ and $\mathrm{Al}_{4}$ polymers contain chloride, which reduces their charge and perhaps promotes polymerization. Chloro complexes may form metastable ion pairs from positively charged $\mathrm{Al}-\mathrm{OH}$ species and chloride anions during the ESI nebulization. These complexes may be stable enough to be detected by quadrupole mass analyzer, i.e., the complexes do not dissociate during the time needed to reach the detector $(c a .100 \mu \mathrm{s})$. Water molecules are coordinated to central aluminum in many hydrolytic polymers; up to five water molecules were found. These complexes are only partially hydrolyzed, and further deprotonation of coordinated water molecules may appear at higher $\mathrm{pH}$ values as a competitive process to prevent further polymerization. However, a different hydrolytic scheme is seen in aged aluminum solutions (Figure 3). The spectrum shows only a few signals which were assigned to $\left[\mathrm{Al}(\mathrm{OH})_{2}\right]^{+},\left[\mathrm{Al}_{6}(\mathrm{OH})_{13}\right]^{5+}$ and $\left[\mathrm{Al}_{4}(\mathrm{OH})_{9}\right]^{3+}$. The most intense peak was given by the aqua aluminum ion; this is understandable because of the relatively low $\mathrm{pH}$ of the solution. Other intense signals belong to tetrameric and hexameric species, indicating that, even at mildly acidic $\mathrm{pH}$, the polymerization proceeds to a significant degree. Upon 
Table 2. Identified species in $2.7 \times 10^{-5} \mathrm{~mol} \mathrm{dm}{ }^{-3}$ solutions of $\mathrm{AlCl}_{3}$ at different $\mathrm{pH}$ values

\begin{tabular}{|c|c|c|c|}
\hline Observed $\mathrm{m} / \mathrm{z}$ & Identified species & $\mathrm{pH}$ & Importance \\
\hline 57 & {$\left[\mathrm{Al}\left(\mathrm{H}_{2} \mathrm{O}\right)_{8}\right]^{3+}$} & $3.59-4.81$ & \\
\hline 61 & {$\left[\mathrm{Al}(\mathrm{OH})_{2}\right]^{+}$} & $3.19-4.81$ & \\
\hline 70 & {$\left[\mathrm{Al}_{2}(\mathrm{OH})_{3} \mathrm{Cl}\right]^{2+}$} & $3.19-4.81$ & chloro species \\
\hline 79 & {$[\mathrm{Al}(\mathrm{OH}) \mathrm{Cl}]^{+}$and/or $\left[\mathrm{Al}(\mathrm{OH})_{2}\left(\mathrm{H}_{2} \mathrm{O}\right)\right]^{+}$} & $3.19-4.81$ & chloro species \\
\hline 97 & {$\left[\mathrm{Al}(\mathrm{OH})_{2}\left(\mathrm{H}_{2} \mathrm{O}\right)_{2}\right]^{+}$} & $3.19-4.81$ & \\
\hline 103 & {$\left[\mathrm{Al}_{2} \mathrm{O}_{2}(\mathrm{OH})\right]^{+}$} & 3.59 & \\
\hline 121 & {$\left[\mathrm{Al}_{2} \mathrm{O}(\mathrm{OH})_{3}\right]^{+}$} & $3.19-4.81$ & \\
\hline 123 & {$\left[\mathrm{Al}_{2}(\mathrm{OH})_{3}\left(\mathrm{H}_{2} \mathrm{O}\right)\right]^{+}$} & $3.19-4.81$ & \\
\hline 133 & {$\left[\mathrm{Al}(\mathrm{OH})_{2}\left(\mathrm{H}_{2} \mathrm{O}\right)_{4}\right]^{+}$} & $3.19-4.81$ & \\
\hline 157 & {$\left[\mathrm{Al}_{2} \mathrm{O}(\mathrm{OH})_{3}\left(\mathrm{H}_{2} \mathrm{O}\right)_{2}\right]^{+}$} & $3.19-4.81$ & \\
\hline 175 & {$\left[\mathrm{Al}_{2} \mathrm{H}_{9} \mathrm{O}_{7}\right]^{+}$and/or $\left[\mathrm{Al}_{2} \mathrm{O}(\mathrm{OH})_{2} \mathrm{Cl}\left(\mathrm{H}_{2} \mathrm{O}\right)_{2}\right]^{+}$} & $3.19-3.59$ & chloro species \\
\hline 217 & {$\left[\mathrm{Al}_{3} \mathrm{O}(\mathrm{OH})_{6}\left(\mathrm{H}_{2} \mathrm{O}\right)\right]^{+}$} & $3.59-4.81$ & oligomer \\
\hline 235 & {$\left[\mathrm{Al}_{3} \mathrm{H}_{10} \mathrm{O}_{9}\right]+$} & 3.59 & \\
\hline 253 & {$\left[\mathrm{Al}_{3} \mathrm{O}(\mathrm{OH})_{5} \mathrm{Cl}\left(\mathrm{H}_{2} \mathrm{O}\right)_{2}\right]^{+}$} & $3.19-4.81$ & chloro species \\
\hline 277 & {$\left[\mathrm{Al}_{4} \mathrm{O}(\mathrm{OH})_{9}\right]^{+}$} & $3.59-4.81$ & polynuclear \\
\hline
\end{tabular}

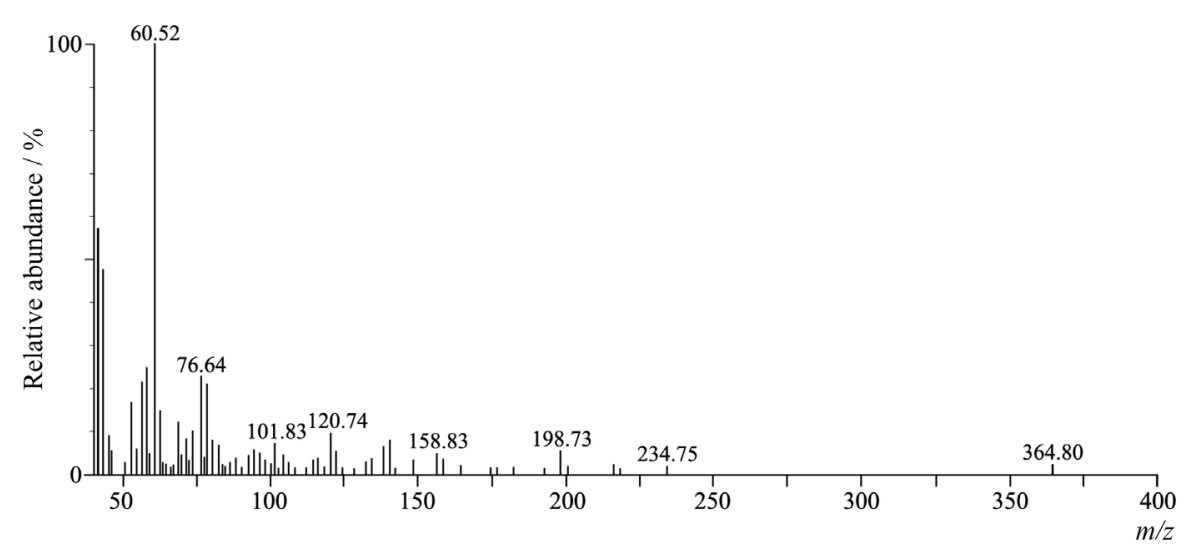

Figure 2. ESI-MS spectra of a $2.7 \times 10^{-5} \mathrm{~mol} \mathrm{dm}^{-3} \mathrm{AlCl}_{3}$ solution, $\mathrm{pH} 3.59$, cone voltage $50 \mathrm{~V}$, taken in water as the mobile phase.

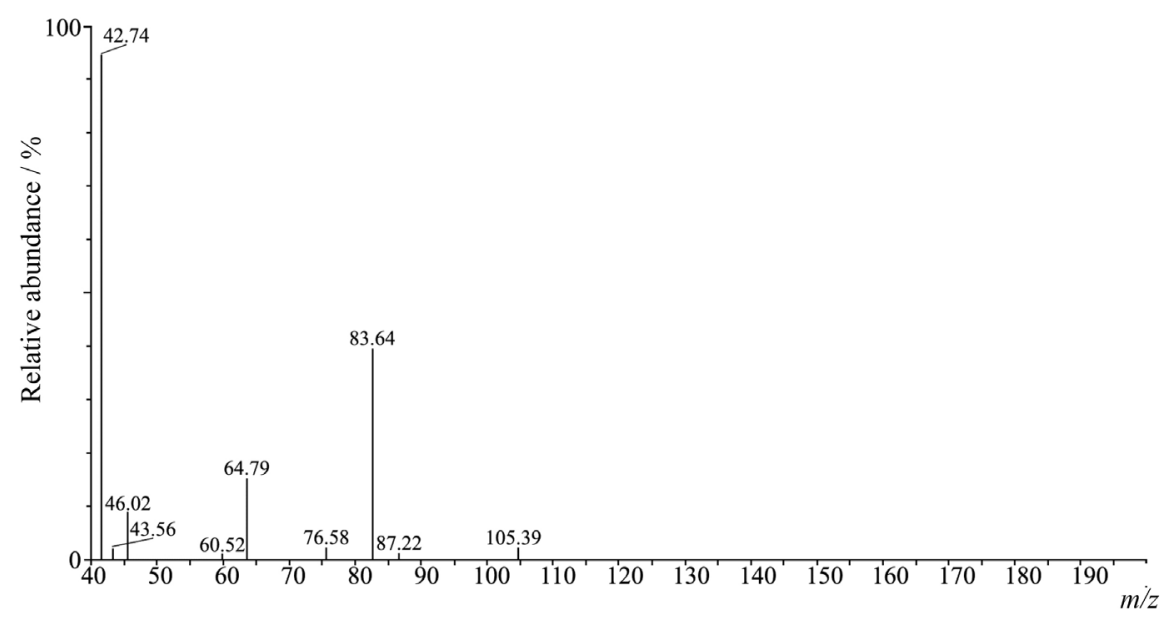

Figure 3. ESI-MS spectrum of a $0.1 \mathrm{mmol} \mathrm{dm}^{-3} \mathrm{AlCl}_{3}$ solution at $\mathrm{pH} 3.30$, aged for one month.

further $\mathrm{pH}$ increase, the intensity of the aqua aluminum ion signal decreases sharply, and new signals appear that can be assigned to species with $\mathrm{Al}_{7}$ to $\mathrm{Al}_{12}$ cores. At $\mathrm{pH}$ between
5.0 and 6.0 most signals disappear from the spectra and only lighter polymer cores $\left(\mathrm{Al}_{2}\right.$ and $\left.\mathrm{Al}_{3}\right)$ were detected in solution before precipitation took place. 

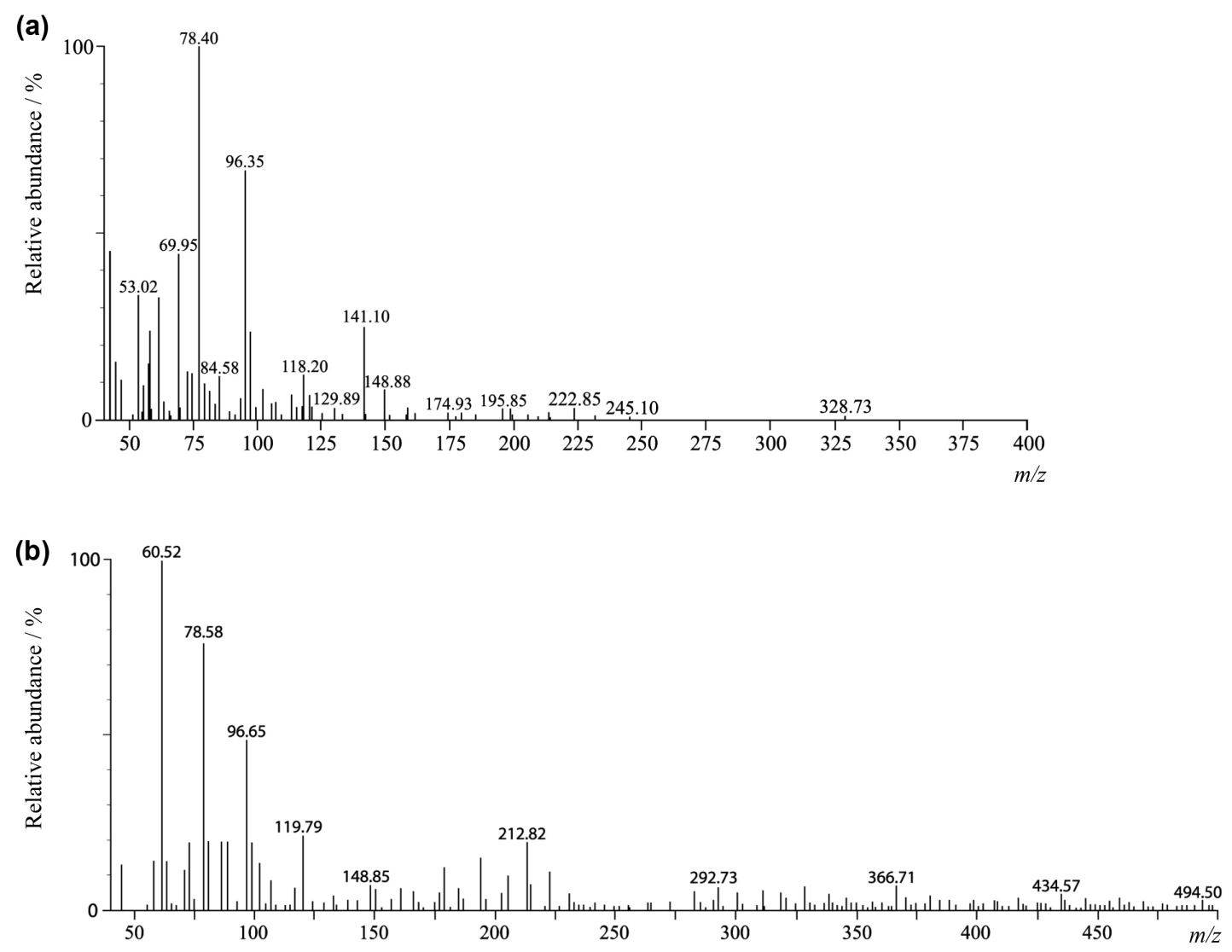

Figure 4. (a) ESI-MS spectrum of a $1.0 \times 10^{-4} \mathrm{~mol} \mathrm{dm}^{-3} \mathrm{AlCl}_{3}$ solution, $\mathrm{pH} 4.35$, sample cone voltage of $50 \mathrm{~V}$. (b) ESI-MS spectrum of $1.0 \times 10^{-3} \mathrm{~mol} \mathrm{dm}^{-3}$ $\mathrm{AlCl}_{3}$ solution, $\mathrm{pH} 4.23,50 \mathrm{~V}$.

The effect of various aluminum concentrations on the MS spectra was investigated at $\mathrm{pH} 4.20$, and aluminum concentrations were varied between $0.1 \times 10^{-3}$ and $1.0 \times 10^{-3} \mathrm{~mol} \mathrm{dm}^{-3}$ with one day of aging time. The representative spectra are shown in Figures $4 \mathrm{a}$ and $4 \mathrm{~b}$. The identified species are shown in Table 3.

For aluminum concentrations in the milimolar range, higher polymers containing $\mathrm{Al}_{8}-\mathrm{Al}_{13}$ cores were observed. The single-charge complexes were observed for $\mathrm{Al}_{1}$ to $\mathrm{Al}_{4}$, as well as for $\mathrm{Al}_{7}$ cores. The +2 and +3 charges were found for $\mathrm{Al}_{8}-\mathrm{Al}_{13}$ cores.

We have also examined the spectra of solutions in which the total concentration of aluminum ion was $5.0 \mathrm{mmol} \mathrm{dm}^{-3}$ at $\mathrm{pH} 4.05$ with relatively high concentration of chloride ion (total chloride $=150 \mathrm{mmol} \mathrm{dm}^{-3}$ ). A representative spectrum is given in Figure 5.

The whole process is clearly composed of two stages. In the first stage the lighter charged particles reach the detector. In the second stage heavier, larger polymers form in the droplets by clustering of oligomers with sodium and chloride ions and possibly water molecules. The transfer of these clusters into the gas phase is unefficient so low intensity signals are produced. It is seen that the majority of complexes contain chloride either as a coordinated ion or as a counter ion. No atempt to identify these polymers was made. Single-charged species prevail at higher $\mathrm{pH}$ values

Table 3. Identified species in $\mathrm{AlCl}_{3}$ solutions with aluminum concentrations from $0.1 \times 10^{-3}$ to $1.0 \times 10^{-3} \mathrm{~mol} \mathrm{dm}^{-3}$ at $\mathrm{pH} 4.20$

\begin{tabular}{|c|c|c|}
\hline Observed $m / z$ & Species & $\begin{array}{c}\text { Concentration of } \\
\text { solution }\left(\mathrm{mol} \mathrm{dm} \mathrm{dm}^{-3}\right)\end{array}$ \\
\hline 61 & {$\left[\mathrm{Al}(\mathrm{OH})_{2}\right]^{+}$} & $1 \times 10^{-4}-1 \times 10^{-3}$ \\
\hline 70 & {$\left[\mathrm{Al}_{2}(\mathrm{OH})_{3} \mathrm{Cl}\right]^{2+}$} & $1 \times 10^{-4} ; 1 \times 10^{-3}$ \\
\hline 79 & $\begin{array}{c}{[\mathrm{Al}(\mathrm{OH}) \mathrm{Cl}]^{+} \text {and/or }} \\
{\left[\mathrm{Al}(\mathrm{OH})_{2}\left(\mathrm{H}_{2} \mathrm{O}\right)\right]^{+}}\end{array}$ & $1 \times 10^{-4}-1 \times 10^{-3}$ \\
\hline 97 & {$\left[\mathrm{Al}(\mathrm{OH})_{2}\left(\mathrm{H}_{2} \mathrm{O}\right)_{2}\right]^{+}$} & $1 \times 10^{-4}-1 \times 10^{-3}$ \\
\hline 133 & {$\left[\mathrm{Al}(\mathrm{OH})_{2}\left(\mathrm{H}_{2} \mathrm{O}\right)_{4}\right]^{+}$} & $1 \times 10^{-4}-1 \times 10^{-3}$ \\
\hline 175 & $\begin{array}{c}{\left[\mathrm{Al}_{2} \mathrm{H}_{9} \mathrm{O}_{7}\right]^{+} \text {and/or }} \\
{\left[\mathrm{Al}_{2}(\mathrm{OH})_{2} \mathrm{Cl}\left(\mathrm{H}_{2} \mathrm{O}\right)\right]^{+}}\end{array}$ & $1 \times 10^{-4}-1 \times 10^{-3}$ \\
\hline 193 & $\begin{array}{c}{\left[\mathrm{Al}_{7} \mathrm{O}_{9}(\mathrm{OH})\left(\mathrm{H}_{2} \mathrm{O}\right)_{2}\right]^{2+} \text { and/or }} \\
{\left[\mathrm{Al}_{2} \mathrm{O}(\mathrm{OH})_{2} \mathrm{Cl}\left(\mathrm{H}_{2} \mathrm{O}\right)_{3}\right]^{+} \text {and/or }} \\
{\left[\mathrm{Al}_{2}(\mathrm{OH})_{4} \mathrm{Cl}\left(\mathrm{H}_{2} \mathrm{O}\right)_{2}\right]^{+}}\end{array}$ & $\begin{array}{c}1 \times 10^{-4} \\
1 \times 10^{-4}-1 \times 10^{-3}\end{array}$ \\
\hline 199 & {$\left[\mathrm{Al}_{3} \mathrm{O}(\mathrm{OH})_{6}\right]^{+}$} & $1 \times 10^{-4}$ \\
\hline 213 & {$\left[\mathrm{Al}_{13} \mathrm{O}_{18}\right]^{3+}$} & $1 \times 10^{-4}-1 \times 10^{-3}$ \\
\hline 247 & {$\left[\mathrm{Al}_{5} \mathrm{O}_{7}\right]^{+}$} & $5 \times 10^{-4}$ \\
\hline 253 & {$\left[\mathrm{Al}_{3} \mathrm{O}(\mathrm{OH})_{5} \mathrm{Cl}\left(\mathrm{H}_{2} \mathrm{O}\right)_{2}\right]^{+}$} & $5 \times 10^{-4}$ \\
\hline 375 & {$\left[\mathrm{Al}_{5} \mathrm{O}_{4}(\mathrm{OH})_{2} \mathrm{Cl}_{4}\right]^{2+}$} & $5 \times 10^{-4}$ \\
\hline 494 & {$\left[\mathrm{Al}_{7} \mathrm{O}_{5}(\mathrm{OH})_{8} \mathrm{Cl}_{2}\left(\mathrm{H}_{2} \mathrm{O}\right)\right]^{+}$} & $5 \times 10^{-4} ; 1 \times 10^{-3}$ \\
\hline
\end{tabular}




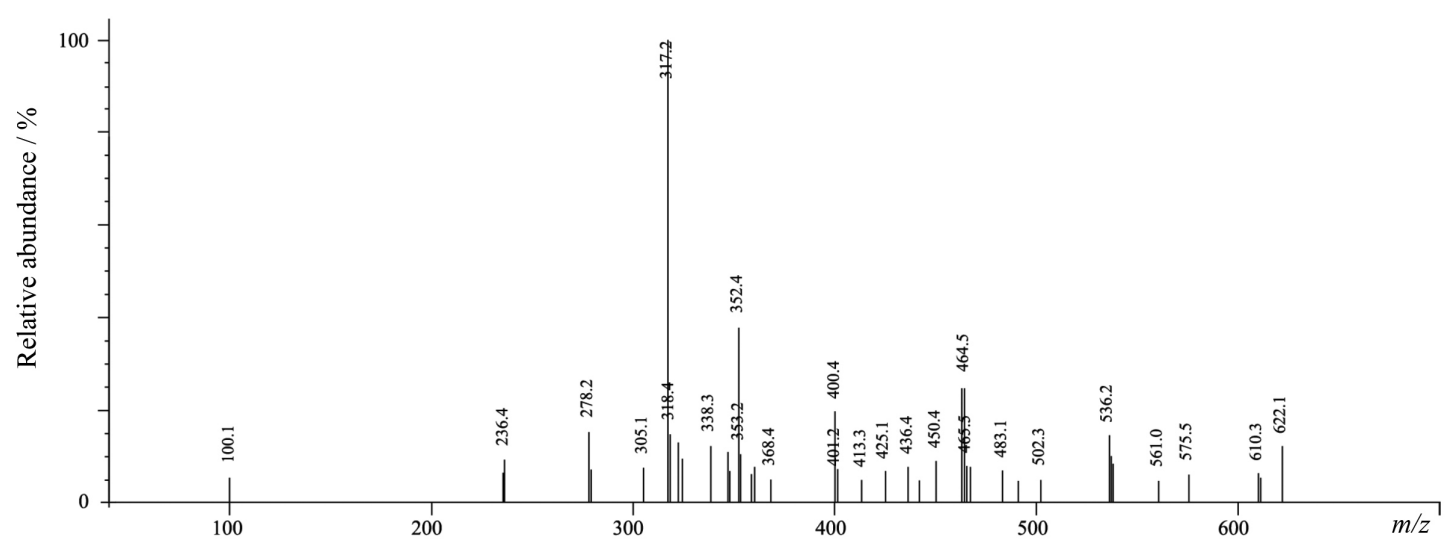

Figure 5. ESI-MS spectra of an aluminum chloride solution $\left(\mathrm{C}_{\mathrm{Al}}=5.0 \mathrm{mmol} \mathrm{dm}^{-3}, \mathrm{C}_{\mathrm{Cl}^{-}}=150 \mathrm{mmol} \mathrm{dm}^{-3}, \mathrm{pH} 4.05\right)$.

(> 4.8). The most intense signals in the whole $\mathrm{pH}$ range investigated could be attributed to $\mathrm{Al}_{2}-\mathrm{Al}_{6}$ cores.

\section{Discussion}

From the general inspection of Tables 2 and 3, it may be seen that the species found in our work are consistent with earlier literature reports, ${ }^{48-54}$ although some of the signals in the recorded mass spectra could not be assigned. The main problems encountered in the interpretation of the ESI-MS spectra are perturbations that occur in the droplets. Three kinds of perturbations may occur in the ESI-MS ion source: in solution, at the liquid-gas interface and in the gas phase. These perturbations may be linked to the formation of hydrolytic polymers in the droplets, different transfer efficiencies from the droplets to the gas phase for different complexes (according to their charge to radius ratio and surface activity), and subsequent partial thermal decomposition of the polymers. ${ }^{53}$

Perturbations in solution occur in the droplets during their evaporation. Evaporation of droplets changes the concentration of dissolved species and consequently causes equilibrium shifts due to $\mathrm{pH}$, concentration, temperature and ionic strength changes. Perturbations at the liquid-gas interface depend upon the radius of the droplets and the surface activity of the ions. These parameters influence the efficiency with which different species are transferred from the droplets to the gas phase and therefore change their concentration. Perturbations in the gas phase are fragmentations or other thermally induced reactions taking place after the transfer of the ions to the gas phase and before their detection. The formation of polymeric hydrolytic complexes can occur as a result of perturbations in the droplets when $\mathrm{Al}^{3+}$ solutions are electrosprayed. Whether the formation of polymeric hydrolytic species is the result of true equilibrium in solution or perturbations in ESI-MS source, it can be judged by comparison of the results obtained by different methods and by tuning the instrumental parameters of ESI-MS.

In ESI-MS the aluminum chloride signal is found at $m / z$ 133. It disappears in solutions in which the $\mathrm{pH}$ is higher than 4.50 and this result is consistent with ${ }^{27} \mathrm{Al} \mathrm{NMR}$ spectra. These spectra were taken at different $\mathrm{pHs}$ in the range of 3.30 to 6.50 . The aqua aluminum ion signal is assigned to $0 \mathrm{ppm}$. The small peak at $0.34 \mathrm{ppm}$ seen in the pH range of 3-5 was attributed to the mono-hydrolyzed species, $\mathrm{Al}(\mathrm{OH})\left(\mathrm{H}_{2} \mathrm{O}\right)_{5}{ }^{2+}$ formed in the first step of the hydrolysis, ${ }^{56}$ while the broad, small intensity peaks at $4.5 \mathrm{ppm}$ that appear at $\mathrm{pH}>4.0$ were attributed to $1 \mathrm{mw}$ species, $\mathrm{Al}_{2}(\mathrm{OH})_{2}\left(\mathrm{H}_{2} \mathrm{O}\right)_{8}{ }^{4+}$ and $\mathrm{Al}_{3}(\mathrm{OH})_{4}\left(\mathrm{H}_{2} \mathrm{O}\right)_{9}{ }^{5+} .{ }^{56}$ In theory, ${ }^{57,58}$ it is possible to find signals from monomers up to $9 \mathrm{ppm}$. However, in this work, signals with $\mathrm{S} / \mathrm{N}$ ratio higher than 3 were not found in this region. Higher hydrolytic polymers produced very broad peaks, seen as an increase in the area between 10 and 40 ppm upon increasing pH. Since these peaks are overlapped and immersed into the background, their analysis by NMR spectroscopy is difficult. Tridecameric or polymeric species containing thirteen aluminum ions, $\mathrm{AlO}_{4} \mathrm{Al}_{12}(\mathrm{OH})_{24}\left(\mathrm{H}_{2} \mathrm{O}\right)_{12}{ }^{7+}$, were identified at $62.5 \mathrm{ppm}^{59,60}$ This polymer begins to form at $\mathrm{pH} c a .4$ and the signal is at the maximum intensity at $\mathrm{pH} c a$. 5.5. Upon further increase in $\mathrm{pH}$, the signal suddenly disappears at $\mathrm{pH} c a$. 6.0 and no NMR evidence is found for the formation of lighter polymers. After a short period of aging, turbidity and flocculation take place in the system. However, ESI-MS indicates the formation of $\mathrm{Al}_{3}-\mathrm{Al}_{8}$ polymers in this $\mathrm{pH}$ range, which may suggest that the Keggin polymer first transforms to lighter polymers before precipitation. The tridecamer contains a tetrahedral aluminum surrounded by twelve octahedral aluminums all bound to each other through oxygen. The tetrahedral aluminum gives a distinct sharp peak at $62.5 \mathrm{ppm}^{59,60}$ relative to the monomeric $\mathrm{Al}\left(\mathrm{H}_{2} \mathrm{O}\right)_{6}{ }^{3+}$. The other twelve aluminums in the tridecamer as well as other large 
amorphous polymeric aluminum species produce a very broad peak around $40 \mathrm{ppm}$ that is not easily integrated because it is not clearly defined. However, the integration between $c a$. 40 to $80 \mathrm{ppm}$ shows that the area increased up to $10 \%$ upon rising the $\mathrm{pH}$ from 5.0 to 6.0 .

Potentiometric titrations were carried out with two different protocols of base addition: in one titration set, each new portion of the base was added (at the rate of $0.05 \mathrm{~mL} \mathrm{~s}^{-1}$ ) five minutes after the potential stabilization, while in the other case the addition of the base was initiated $20 \mathrm{~min}$ after the potential stabilization, at the same rate. Further sets of titrations were made in such a way that, at some definite value of $\mathrm{pH}$, the addition of the base was stopped until the potential readings taken over a prolonged period of time showed relative standard deviation less than $3 \%$. Titration curves showed pronounced hysteresis in the region in which the titration parameter $(a)$ ranged between 1.0 and 1.5 (Figure 6). Up to $a$ close to 0.2 , the solutions remained clear even for a prolonged period of time. Titration curves obtained under different kinetic conditions coincided up to $a$ values close to 0.2 (Figure 6). With higher values of $a$, relatively fast addition of the base did not produce visible changes in the solutions and the potentials remained steady. However, leaving such solutions for one or more hours without the addition of the base, unsteady potentials (relative standard deviation in potential readings $>5 \%$ ) with slight opacity were produced. Further increase of the titration parameter led to the formation of microcolloids and, at $a$ close to 1, a permanent precipitate was formed. Thus, the broad region of the titration curves involving the plateau and the steep rise of $\mathrm{pH}$ (Figure 6) corresponds to a meta-stable state with the main step attributable to the formation of soluble $\mathrm{Al}(\mathrm{OH})_{3(\text { aq }}$. These species subsequently form a supersaturated solution, and when the number of nucleation centers reaches a critical

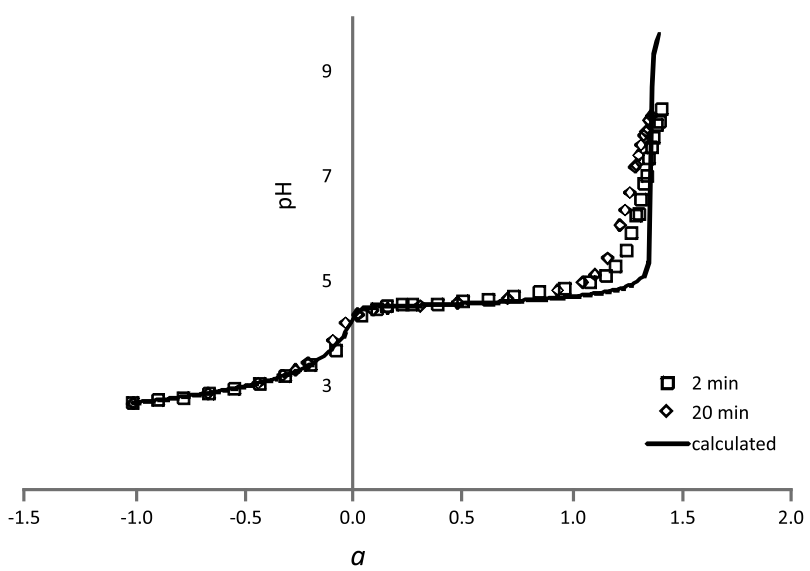

Figure 6. Titration curves of $\mathrm{AlCl}_{3}$ solutions with two different titration protocols. The solid line denotes the titration curve calculated with the data given in Table 4. value, it begins to condense by forming polymeric rings, and precipitates. Attempts to fit these titration curves with sets of complexes taken from databases (Table 4), gave an excellent fit up to $Z$ (hydroxyl to aluminum ratio) close to 1.0. At higher values of $Z$, the calculated curve goes closer to the experimental curve obtained with slow base addition.

Table 4. Literature data on aluminum hydrolytic complexes ${ }^{61-63}$

\begin{tabular}{lc}
\hline Species & $\log \beta$ \\
\hline $\mathrm{AlH}_{-1}$ & -5.5 \\
$\mathrm{AlH}_{-2}$ & -11.3 \\
$\mathrm{AlH}_{-3(\mathrm{aq})}$ & -16.3 \\
$\mathrm{AlH}_{-4}$ & -6.96 \\
$\mathrm{AlH}_{-5}$ & -43.1 \\
$\mathrm{Al}_{2} \mathrm{H}_{-2}$ & -7.7 \\
$\mathrm{Al}_{3} \mathrm{H}_{-4}$ & -13.9 \\
$\mathrm{Al}_{3} \mathrm{H}_{-11}$ & -63.0 \\
$\mathrm{Al}_{6} \mathrm{H}_{-15}$ & -60.7 \\
$\mathrm{Al}_{8} \mathrm{H}_{-22}$ & -93.0 \\
$\mathrm{Al}_{13} \mathrm{H}_{-22}$ & -106.1 \\
$\mathrm{AlH}_{-3(\mathrm{~s})}$ & -10.3 \\
\hline
\end{tabular}

Differences between ESI and potentiometric speciation are observed for species which are detected by ESI with different number of acidic protons, that is, with different charges. The data available in the literature ${ }^{64,65}$ showed the key role of the radius ( $r$ ) of the droplets in determining the relative intensity of the ESI-MS ions. The radius can affect directly the effectiveness by which the ions are transferred to gas phase. Solution perturbations can be increased by larger droplets. Since the passage of the ions to the gas phase is delayed, this gives the reactions in the droplets more time to occur. At the same time, larger $r$ values increase the gas phase concentration of surface active complexes and decrease that of surface inactive complexes.

Comparing ESI-MS, NMR and potentiometric data, it can be concluded that the best agreement was obtained with low molecular mass hydrolytic species. This probably results from the fact that, in polymerized aluminum solutions, the density and viscosity of the solution increase with consequent increase of the surface tension of the droplet. Thus, higher energies are needed to pinch out the higher molecular weight species from the droplet.

\section{Conclusion}

The ESI-MS technique was successfully applied in the study of aluminum hydrolysis in chloride-containing 
aqueous medium. Low molecular weight hydrolytic species with +1 and +2 charge prevail in solution in the $\mathrm{pH}$ range 3-6 and at mild ESI conditions. Higher polymers, $\mathrm{Al}_{5}$ to $\mathrm{Al}_{13}$, are transient species seen at $\mathrm{pH}$ values higher than 4.5 and shortly after preparing the solution. Aging of solutions with $\mathrm{pH}$ values up to 6 did not produce polymers higher than $\mathrm{Al}_{13}$. Most polymeric species contain chlorides bound directly to aluminum ions.

\section{Acknowledgement}

The financial aid from the Ministry of Education and Science of Serbia under the project grant 172016 is gratefully acknowledged.

\section{References}

1. Baes, C. F.; Mesmer, R. E.; The Hydrolysis of Cations; John Wiley \& Sons: New York, 1976.

2. Nazarenko, V. A.; Antonovich, V. P.; Nevskaya, E. M.; Gidroliz Ionov Metallov v Razbavlennykh Rastvorakh; Atomizdat: Moscow, 1979.

3. Hayden, P. L.; Rubin, A. J. In Aqueous Environmental Chemistry of Metals; Rubin, A. J., ed.; Ann Arbor Science Publishers: An Arbor, MI, 1974.

4. Orvig, C. In Coordination Chemistry of Aluminum; Robinson, G. H., ed.; VCH Publishers: New York, 1993, p. 85.

5. Nordstrom, D. K.; May, H. M. In The Environmental Chemistry of Aluminum; Sposito, G., ed.; CRC Press, Inc. Lewis Publishers: Boca Raton, FL, 1996, p. 39.

6. Öhman, L.-O.; Sjöberg, S.; Coord. Chem. Rev. 1996, 149, 33.

7. Wesolowski, D. J.; Palmer, D. A.; Geochim. Cosmochim. Acta 1994, 58, 2947.

8. Palmer, D. A.; Wesolowski, D. J.; Geochim. Cosmochim. Acta 1993, 57, 2929.

9. Akitt, J. W.; Elders, J. M.; Bull. Soc. Chim. Fr. 1986, 10.

10. Bertsch, P. M.; Parker, D. R. In The Environmental Chemistry of Aluminum; Sposito, G., ed.; CRC Press, Inc. Lewis Publishers: Boca Raton, Fl, 1996, p. 117.

11. Brosset, C.; Biedermann, G.; Sillén, L. G.; Acta Chem. Scand. 1954, 8, 1917.

12. Brown, P. L.; Sylva, R. N.; Batley, G. E.; Ellis, J.; J. Chem. Soc., Dalton Trans. 1985, 1967.

13. Martell, A. E.; Hancock, R. D.; Smith, R. M.; Motekaitis, R. J.; Coord. Chem. Rev. 1996, 149, 311.

14. Browne, B. A.; Driscoll, C. T.; Science 1992, 256, 1667.

15. Frippiate, J. J.; Van Cauwelaert, F.; Bosmans, H.; J. Phys. Chem. 1965, 69, 2458.

16. Akitt, J. W.; Elders, J. M.; J. Chem. Soc., Dalton. Trans. 1988, 1347.
17. Matijević, E.; Stryker, L. J.; J. Colloid Interface Sci. 1966, 22, 68.

18. Shen, Y.-H.; Dempsey, B. A.; Environ. Int. 1998, 24, 899.

19. Parks, G. A.; Am. Mineral. 1972, 57, 1163.

20. Aveston, J.; J. Chem. Soc. 1965, 4438.

21. Matijević, E.; Težak, B.; J. Phys. Chem. 1953, 57, 951.

22. Matijević, E.; Mathai, K. G.; Ottewill, R. H.; Kerker, M.; J. Phys. Chem. 1961, 65, 826.

23. Bottero, J. Y.; Tchoubar, D.; Cases, J. M.; Flessinger, F.; J. Phys. Chem. 1982, 86, 3667.

24. Seichter, W.; Mögel, H.-J.; Brand, P.; Salah, D.; Eur. J. Inorg. Chem. 1998, 1998, 795.

25. Milic, N. B.; Bugarcic, Z. D.; Djurdjevic, P. T.; Can. J. Chem. 1991, 69, 28.

26. Bottero, J. Y.; Cases, J. M.; Fiessinger, F.; Poirier, J. E.; J. Phys. Chem. 1980, 84, 2933.

27. Hayden, P. L.; Rubin, A. J. In Aqueous-Environmental Chemistry of Metals; Rubin, A. J., ed.; Ann Arbor Science Publishers: Ann Arbor, MI, 1976, p. 317.

28. Sillén, L. G.; Q. Rev. Chem. Soc. 1959, 13, 146.

29. Turner, R. C.; Ross, G. J.; Can. J. Chem. 1970, 48, 723.

30. Turner, R. C.; Can. J. Chem., 1976, 54, 1910.

31. Parker, W. O.; Millini, R.; Kiricsi, I.; Inorg. Chem. 1997, 36, 571.

32. Stumm, W.; Morgan, J. J.; Aquatic Chemistry, $2^{\text {nd }}$ ed.; John Wiley \& Sons: New York, 1981.

33. Akitt, J. W.; Prog. Nucl. Magn. Reson. Spectrosc. 1989, $21,1$.

34. Akitt, J. W.; Greenwood, N. N.; Khandelwal, B. L.; Lester, G. D.; J. Chem. Soc., Dalton. Trans. 1972, 604.

35. Akitt, J. W.; Farthing, A.; J. Chem. Soc., Dalton. Trans. 1981, 1606.

36. Bi, S.; Wang, C.; Cao, Q.; Zhang, C.; Coord. Chem. Rev. 2004, $248,441$.

37. Keggin, J. F.; Nature 1933, 131, 908.

38. Keggin, J. F.; Proc. R. Soc. London, Ser. A 1934, 144, 75.

39. Baker, L. C. W.; Figgis, J. S.; J. Am. Chem. Soc. 1970, 92, 3794.

40. Allouche, L.; Gérardin, C.; Loiseau, T.; Férey, G.; Taulelle, F.; Angew. Chem., Int. Ed. 2000, 39, 511.

41. Johansson, G.; Acta Chem. Scand. 1960, 14, 771.

42. Casey, W. H.; Rustad, J. R.; Ann. Rev. Earth Planet. Sci. 2007, $35,21$.

43. Fu, G.; Nazar, L. F.; Bain, A. D.; Chem. Mater. 1991, 3, 602.

44. Wang, M.; Muhammed, M.; Nanostruct. Mater. 1999, 11, 1219.

45. Shi, B.; Li, G.; Wang, D.; Tang, H.; Sep. Purif. Technol. 2007, $54,88$.

46. Bradley, S. M.; Kydd, R. A.; Fyfe, C. A.; Inorg. Chem. 1992, $31,1181$.

47. Casey, W. H.; Phillips, B. L.; Karlsson, M.; Nordin, S.; Nordin, J. P.; Sullivan, D. J.; Neugebauer-Gawford, S.; Geochim. Cosmochim. Acta 2000, 64, 2951.

48. Urabe, T.; Tsugoshi, T.; Tanaka, M.; J. Mol. Liq. 2008, 143, 70. 
49. Urabe, T.; Tanaka, M.; Kumakura, S.; Tsugoshi, T.; J. Mass Spectrom. 2007, 42, 591.

50. Zhao, H.; Liu, H.; Qu, J.; J. Colloid Interface Sci. 2009, 330, 105.

51. Sarpola, A.; Hietapelto, V.; Jalonen, J.; Jokela, J.; Laitinen, R. S.; J. Mass Spectrom. 2004, 39, 423.

52. Sarpola, A.; Hellman, H.; Hietapelto, V.; Jalonen, J.; Jokela, J.; Rämö, J.; Saukkoriipi, J.; Polyhedron 2007, 26, 2851.

53. Sarpola, A.; The Hydrolysis of Aluminum, a Mass Spectrometric Study, PhD Thesis, University of Oulu, Finland, Acta Univ. Oul. 2007, C 279, 1.

54. Sarpola, A.; Hietapelto, V.; Jalonen, J.; Jokela, J.; Laitinen, R. S.; Rämö, J.; J. Mass Spectrom. 2004, 39, 1209.

55. Deng, H.; Van Berkel, G. J.; J. Mass Spectrom. 1998, 33, 1080.

56. Perry, C. C.; Shafran, K. L.; J. Inorg. Biochem. 2001, 87, 115.

57. Tossell, J. A.; J. Magn. Reson. 1998, 135, 203.

58. Kubicki, J. D.; Sykes, D.; Apitz, S. E.; J. Phys. Chem. A. 1999, 103, 903.

59. Kloprogge, J. T.; Seykens, D.; Geus J. W.; Jansen, J. B. H.; J. Non-Cryst. Solids 1992, 142, 87.
60. Casey, W. H.; Chem. Rev. 2006, 106, 1.

61. Pettit, L.; Powell, J. K.; Stability Constant Database and MiniSCDatabase, version 5.8.; IUPAC and Academic Software: Otley, UK, 2008.

62. Smith, R. M.; Martell, A. E.; Motekaitis, R. J.; NIST Critically Selected Stability Constants of Metal Complexes Database, version 8.0. for Windows; U. S. National Institute of Standards and Technology: Gaithersburg, MD, 2004.

63. May, P. M.; Rowland, D.; Murray, K.; JESS-Joint Expert Speciation System, version 6.4; Murdoch University: Perth, Australia, 2005.

64. Di Marco, V. B.; Ravene, L.; Dean, A.; Traldi, P.; Rapid Comm. Mass Spectrom. 2010, 24, 868.

65. Di Marco, V. B.; Bombi, G. G.; Zambon, S.; J. Mass Spectrom. 2009, 44, 120.

Submitted: October 24, 2011

Published online: May 15, 2012 